\title{
DOES PARTICIPATION IN UNIVERSITY GOVERNANCE ADD VALUE TO A STUDENT'S ACADEMIC EXPERIENCE?
}

\author{
V. Mthethwa \\ Department of Human Resources \\ Durban University of Technology \\ Durban, South Africa \\ e-mail: mthethwavl@gmail.com / https://orcid.org/0000-0002-3740-6288
}

\section{Chikoko}

School of Education

University of KwaZulu-Natal

Durban, South Africa

e-mail: chikokov@ukzn.ac.za / https://orcid.org/0000-0001-6135-6172

\section{ABSTRACT}

During the Apartheid period in South Africa, students at Historically Black Universities were excluded from participating in institutional decision-making affecting their enrollment, fee allocation, academic challenges and general well-being. The Higher Education Act of 1997, changed this situation to a participatory inclusion of the Student Representative Council in university governance where they could influence and promote students' academic interests. This article draws from a study that was conducted at selected Black universities, to explore the academic benefits derived by students who participated in governance since the change. Issues of free education that have been topical in South Africa and further pose scrutiny on how this achievement is beneficial to the SRC who are central to student development advocacy. Adopting a qualitative research approach, the study sought to understand the academic experiences of the $\mathrm{SRC}$, as participants in the highest decision-making structures at these institutions. Findings from the study suggest that the academic benefit for the SRC as participants in governance is dependent on their level of study, political deployment, time commitments and academic aspirations. There ought to be a deeper interrogation on how best to ensure academic value for students who participate in governance.

Key words: academic value, student participation, university governance

\section{INTRODUCTION AND BACKGROUND}

It has been 23 years since the enactment of the Higher Education Act No. 101. One of the highlights of this legislation is the incorporation for the first time of the Student Representative Council (SRC) in institutional governance. Based on the Act, the SRCs now have formal seats in the Council of their universities (the highest decision-making body), Senate (the highest 
decision-making structure on academic issues) and the highest advisory body at these institutions, the Institutional Forum (Koen, Cele and Libhaber 2006).

The incorporation of students in university governance, is rooted in the establishment of separate universities in South Africa (SA) based on racial divisions. Historically, there were a number of discriminatory-based legislation directly linked to the Apartheid policy of government. Amongst these, the Extension of University Education Act No.45 of 1959 prohibited the admissions of Africans to Historically White Universities (HWUs), while creating separate universities for Africans, known as Historically Black Universities (HBUs). According to Davies (1996) HBUs included the University College of Zululand (now University of Zululand), the University College of the North (now University of Limpopo) and the University College of Fort Hare (now University of Fort Hare). To this list, Robus and Macleod (2006) add the University College of Western Cape (now University of Western Cape). Scholars have pointed out that student activism historically was a direct response to Apartheid discriminatory practices that existed at Higher Education Institutions (HEIs) in South Africa (Reddy 2004; Cele 2008; Soudien 2010). Between 1970 and 1990, students particularly in the HBUs, played a pivotal role in raising consciousness about the inequalities that existed in HEIs (Altbach and Cohen 1990).

Mapesela and Hay (2005) highlight that during Apartheid, students were not given opportunities to voice their concerns on tuition, the academic programmes offered and accommodation challenges they faced. As a result of the inequalities in educational access, student protests were rife leading to the establishment of the African National Congress Youth League in 1944 and further increase of Black organisations in the 1950s (Badat 1999). The formation of the South African Student Organisation (SASO) in 1968, highlighted student mobilisation against higher education discriminatory practices and the quest to have the SRC recognised at HBUs. Cele and Koen $(2003,7)$ stress that "black universities became the seedbeds of protest" supported by political formations.

The upsurge of student protests at HBUs between 1960s and 1980s heightened the pressure for change culminating in the promulgation of the Higher Education Act in 1997. This Act changed the landscape of HEIs to now include the SRC as participants in university governance and therefore provided them the platform to influence issues related to student development. Against this background, this article specifically examines the academic benefit that the SRC members derive from their participation in governance.

\section{STATEMENT OF THE PROBLEM}

Despite the incorporation of students in university governance to influence their academic 
pursuits, the plethora of literature that exists on this involvement is largely on student political activism (Altbach 2006; Klemenčič 2014; Koen et.al. 2006). Nyundu, Naidoo and Chagonda (2015) observe the benefits students gained from their participation to be largely linked to their aspirations to participate in national politics. The burgeoning literature on \#FeesMustFall, \#OpenStellies, \#SteynMustFall, \#UPrising, \#UFSShutdown (Luescher, Loader and Mugame 2017) show political formations being at the forefront of these uprisings. Thathiah (2016) further argues that where students were seen to be destroying their institutional facilities, this would be counterproductive to the very basis for academic pursuit. At the point of contestation for positions in the SRC, Luescher and Klemenčič (2017) and Mazwai (2008) agree that most of the students are partisan aligned. This suggests a strong political influence on the students at the point of their election as SRC members.

Specific to the legislative prescripts, there are no guidelines on the role of the SRC in governance structures. Bonakele, Mxenge, Thabakgale and Tabane (2003) confirm that the SRC Constitution is "the supreme law of the student body and no other student law may contradict with its provisions". This confirms that the SRC Constitutions guide all SRC activities including their governance participation.

Ironically the constitutions do not articulate any obligatory academic commitments linked to their roles as the SRC, except the requirement to be registered and have progressed academically at the point of contestation. Once students are elected to the SRC, there are no further academic obligations during the course of their term. There is a gap in understanding the academic experience of the SRC during their participation in governance. This study attempts to fill this void by investigating the academic value that the SRCs derive from their governance participation.

\section{THEORETICAL FRAMEWORK}

We selected Tinto's $(1987 ; 1993)$ integration theory and Astin's $(1984 ; 1999)$ theory of involvement as our theoretical framework on issues of academic progress, specific to the SRC. These theories were purposely chosen since both examine the influences on student academic persistence and success, which is the main purpose of this study. We examine the academic progress by students in the SRC.

Tinto (1987) posits that the decision by students to persist or depart at institutions of higher learning, is prompted by the nature of the academic and social integration that takes place. Factors that determine the nature of this integration include the individual's (i) social and academic background; (ii) their goals, commitments and intentions. These converge to determine whether such a relationship is positive or negative. For Tinto (1987), a sufficient 
balance between students' academic and social integration will determine the nature of their academic experiences. Further students' own background, goals, commitments and intentions contribute to this manifestation. While we buy into Tinto's integration theory, we also propose a third form of integration namely governance integration, that is one's ability to deeply understand university governance issues and being able to add value to the decision-making processes therein. Cutting-edge university governance issues include strategic planning, university politics, finances, conflict management and resolution, and discipline management. Within the context of Tinto's theory, we would anticipate that if students are now members of the highest level of decision-making, they ought to gain academically, from being in a position of influence, about their studies.

Astin $(1984 ; 1999)$ postulates five features to students' involvement in university life: the investment of psychological and physical energy in the student experience, the continuum of involvement being dependant on the object and time, the effectiveness of policy or practice on increasing student involvement, the qualitative and quantitative features of student involvement, and the relationship of the amount of learning and development to the capacity of student involvement. Astin (1984) states that the nature of student experience and development would be determined by the combination of their investment in academic and extracurricular activities. In this study, the extracurricular activity examined is that of students' governance participation. It would be envisaged that students would be able to balance their commitment to governance with their academic responsibilities, which would yield academic success.

In the context of this study, academic experience refers to the process of students' academic observing, acquisition, undertaking, encountering, performing, integrating, growth and development that builds students holistically in university life, preparing them for their future career aspirations. The two theories adopted are relevant to this study in examining various influences to student academic progress, albeit within the context of integrating their governance roles with their academic aspirations.

\section{RESEARCH DESIGN}

A qualitative research design was used in this study. To understand the relationship between participation in university governance and the academic experiences of the SRC, it was important to obtain the participants' perspectives about the meaning of their lived experiences (Lewis and Ritchie 2003).

\section{Data collection}

We employed a multi-site case study design (Yin 2003) of three HBUs. The study is about 
understanding the specific contexts at the HBUs selected, given the historical disadvantages and previous exclusions of students in governance structures at these particular institutions. Yin (2003) and Merriam (2009) suggest that a key feature in using case studies, is the opportunity for the investigator to establish in-depth information about a particular issue within defined boundaries. Merriam (2009) further claims that case studies are advantageous not only in explaining multiple perspectives but the nuances of real-life experiences. We sought to speak to the SRC at the specific type of institutions about their academic experiences within the context of their inclusion in university governance and therefore the choice of a case study was appropriate.

According to Bryman (2008) purposive sampling refers to the purposeful selection of participants for their relevance to the research topic, specifically addressing the phenomena under research. Our choice of the SRCs as our sample was the most suitable to respond to our study objective as participants in university governance and registered as students. Astin (1984) asserts that students involved in governance tend to have a greater connection to the institution. This implied that their governance participation would advance their academic (i) diligence, (ii) commitment and (iii) accountability.

While the intention was to target SRC members with similar portfolios to make direct comparisons across the three institutions, this could not be enforced given our reliance on their participation being voluntary and out of their own volition. The final roles of the participants interviewed include President (P), Deputy-President (DP), Campus Premier (CP) SecretaryGeneral (SG), Deputy Secretary-General (DSG), Treasurer (T), Academic Officer (AO), Student Services Officer (SSO) and Projects and Internationalisation Officer (PIO).

We interviewed a total of eighteen members of the SRCs from the selected institutions. Boyce and Neale (2006) assert that interviews provide an in-depth insight and knowledge of the experiences of the targeted population, in this case the SRC.

Of the eighteen participants, eleven were undergraduate students in their second or third year of their studies. It should be noted that according to the SRC constitutions (Bonakele et al. 2003), students in their first year of study would not be legible given the obligation to have passed university studies in the year preceding their nominations. The other seven participants were doing their postgraduate studies, meaning they would have completed their initial degrees. While most of the participants were members of at least two governance structures, the two Presidents, two Secretary-Generals and one Deputy-President interviewed, participated in at least six institutional committees. Both Secretary Generals and the Deputy-President interviewed were undergraduate students, while the two Presidents were postgraduate.

The interview instrument was supplemented by an analysis conducted on the SRC 
constitutions. SRC constitutions (documentary analysis) were reviewed to enrich the understanding and meaning (Bowen 2009) about the SRC in governance in order to establish its impact on the academic experiences of the participants.

\section{Data analysis}

Data was analysed through an inductive process to draw patterns, categories and key themes (Silverman 2011). The first level of analysis involved reading and re-reading the transcripts generated from the interviews. This information was then reviewed against the documents (SRC constitutions) that we had obtained from the institutions, referred as cross-data analysis (Cohen Manion and Morrison 2007). In the second stage, the data was then placed into various categories using a color-coding strategy. In the final stage, we conducted a cross-case analysis wherein we compared the themes established across the different sites to determine the overall key themes.

In this report, we present the data through emerging themes. Importantly, the trustworthiness of the findings was achieved through four key elements of credibility, dependability, transferability and confirmability (Bless, Higson-Smith and Sithole 2013). Credibility was enhanced through the selection of HBUs with similar contexts. The generation of data at three similar institutions increased the level of confirmability of the study. Dependability was achieved through the selection of participants with similar portfolios. Having selected only HBUs for this study, transferability could not be achieved to other types of institutions that exist in South Africa that have SRC structures.

\section{Ethical issues}

Regarding ethics, the necessary permission to conduct the study was obtained from all institutions, as well as ensuring the necessary informed consent from the participants (Cohen et al. 2007). In reporting on the findings, pseudonyms were used; this in keeping with the anonymity and confidentiality commitment we had made to the participants. Further the source from which the participants were drawn are numbered against the abbreviation of each role of the participant quoted. For example, we refer to Mvelo (pseudonym) as Mvelo (CP2) and Thenjiwe (pseudonym) as Thenjiwe (DP1).

\section{FINDINGS}

Based on our analysis of the data from the cases, four themes emerged: (a) the paradox of academic aspirations; (b) political deployment; (c) time catalyst; (d) study levels. 


\section{The paradox of academic aspirations}

We questioned participants about their views regarding the academic requirements to qualify for contestation in the SRC. A key theme that permeated the conversations with the participants was the importance of education to compete for positions in governance and their recognition by other students.

Participants recognized the value of the academic threshold to qualify for consideration to serve in the SRC. Dominic (SSO2) stated,

"I think it's the best requirement as it motivates leaders to excel in academics and also in terms of leading by example to the students. You are an advocate for academic excellence and you must be there representing the students and cannot be suffering academically to do this. Some of the cases we are dealing with are that of academic exclusions and therefore you cannot serve students on this, if you have the same challenge. I think it's a good requirement."

Dominic's personal academic commitment is largely influenced by a motivation to demonstrate academic success to increase his value to his peers, being strongly reliant on them to vote him into office. Naturally with the dependency from the students to be elected, the motivation to profile their importance was inevitable.

Portia (A02) expressed a similar sentiment about the importance of the threshold as a student representative stating,

"Kakhulu - kumele si Represente (Very important as we must represent) the students and if you do not pass how can faculty take you seriously when you bring student problems to them - they won't listen to you otherwise. Kodwa kunzima (But it is difficult) to keep up with our own studies."

Demonstrable personal academic progress was important to Portia as the Academic Officer. This was due to the fact that her core functions entailed liaising with faculties on academic challenges faced by students. Ironically her efforts to advocate on academic issues directly with faculties and participating in Senate, meant that this would take its toll on her own academic programme. The notion of being an undergraduate suggests that she would need to sacrifice her academic commitments to attend to the academic challenges faced by her peers, given that such meeting times coincide with her lecture periods. Ironically, while students believed their roles to contribute towards students as the main stakeholder, in Portia's view, the resultant effect was her preparedness to forego her own academic needs. Portia argues further that while they are expected to advocate for students' academic needs, she felt ill-prepared to do so at the meetings. She stated, "at Senate it's very difficult really to participate as mostly all the senior members of the university are there and it can be very scary". This comment 
challenges her confidence in making a contribution on issues pertaining to student development. As such, the many hours she spent at these meetings did not appear to have any visible gain for students. She was likely to suffer academically having missed her lectures for such meetings. This difficulty she experienced, led to her sentiment that the institution,

"ought to provide facility for us to access notes after hours, uhmmm maybe tutors to help us understand and catch up what we have missed. Even in those meetings, maybe if we were trained before on our role and how we can contribute, there would be less pressure and we can balance better with our academics."

Portia further indicates the lack of prior training provided to the SRC to enable their improved understanding and meaningful contribution at the decision-making fora. From her point of view, a more in-depth knowledge about their governance role, would enable them to better serve the academic interests of students and specifically help them find avenue to express their own academic challenges.

Another paradox presented during our discussions with some of the participants, was that while motivated to join the SRC to obtain an academic qualification to come out of the dire socio-economic circumstances they were in, their academic progress was severely compromised by their SRC responsibilities. Mlondi (SG2) shares his own story,

"I grew up in a place where I was actually exposed to poverty. I experienced being helpless and I then joined politics so that I'll be in strategic centres to change my own poverty situation. What basically motivates me here at school is that even if I spend more time in the office, it's for the benefit of the poor and helpless students. What motivates me is that I'm helping people who can't help themselves."

A similar sentiment was expressed by Themba (P3),

"I really wish to contribute to the life of the poor. I just want to see a young, black child being developed. Because I know they're diamonds, it's just that they're dusty they need to be shined. Maybe it's just that I come from a poor background I know how smart they are, it's just that they need resources, they need someone who can develop them."

Both Mlondi and Themba affirmed they joined the SRC to obtain financial rebates to allow them to continue their studies, without the burden of university fees. Themba's comments infer to an untapped community whose potential needs to be identified and enhanced through academic opportunity, including his own similar background. However, the pressure they experienced once in office, particularly in the case of Mlondi as the administrator, suggests that the time spent in office was largely compliance-focused, instead of a genuine attention to 
changing his and others' circumstances. By his own admission,

"We spend the whole day in Council, mostly just listening to the discussions. There is very little contribution we can make because we don't really understand what they are talking about. Even though sometimes I can see that they are talking about money but now I can't read and interpret financial statements. It is difficult for me to see how students can be assisted."

Mlondi's comments demonstrate a minimal opportunity to express the financial burden students face, within the context of university income streams and financial allocations made by universities. His presence at such meetings appears to be confined to marking a register as opposed to a deep engagement on student matters.

From the stipulations in the SRC constitution, all three institutional guidelines promote academic excellence as their objective. These institutions set an academic threshold obliging students to pass their studies in the year preceding their nomination for positions. However once students are elected into office, no further academic obligation is stipulated in all institutional SRC constitutions. Participants admit to achieving the required academic requirement to ensure they qualified for positions in the SRC, however once in office, could not sustain it. Aphiwe (CP2) explained,

"I'll be honest with you when I was not in SRC I attended most lectures to make sure I can pass. But then when I became a member of student services, it became more important to be in the office. This year, I have only attended about four lectures this semester."

The notion of the SRC committing to student advocacy because it is expected or promised while contesting in the elections to a reduced commitment to their studies once in office, has a diminishing value in their quest for academic development.

\section{Political deployment}

Political influence was evident in most participants' responses. While contesting for SRC positions did not require any political affiliation, nor was it stated in the constitution, the majority of the participants' point of entry was directly linked to political dispositions. Teboho (SG1) attests to the strong influence of politics on how students are nominated and elected. He states,

"You have to come from an organisation to participate in SRC. Also, if you want to be in the SRC, you have to be nominated or you have to be recommended by that political party into student governance. Again when in office, the political party to which you are affiliated expects you to promote its policies and programmes." 
Dominic (SSO2) confirmed the close link between students and the political environment, saying,

"Yes, I am a SASCO deployee in good standing. The portfolios are chosen by the deployers, if I can put it like that. When we won the SRC elections, they told me which position I would occupy. If there are disagreements, these are thrashed out at our political meetings."

Melusi (AO3) affirmed this experience,

"Because I signed a form and joined as a member of SASCO, the leadership of that branch said to me, 'chief, you are going to contest' and then I say 'no, I'm not available' and then they persuaded me and up until then I see a reason of doing it. We must continue to promote the policies of our constituency."

Again, Aphiwe (CP2) confirmed the influence of his political affiliation to contest for the SRC,

"I was deployed to this role by my political organisation as they felt that there was something in me that could help students. As Campus Premier this role does not have any link to my studies at all, it's different. There is nothing from my work in the SRC that can help me with my studies. Who benefits are the students that I serve, as their problems are attended to."

The obligation to account to their political constituency invariably affected how they discharged their roles, consequently compromising their academic focus both as representatives of students and their own progression. Mvelo (CP2) admits,

"Sometimes there are internal squabbles based on political affiliation. Sometimes a member would be doing something wrong and you would be attacking the member but the members who are deployed with him would want to protect him, although they see that clearly this person has done something wrong."

An element of how partisan influenced academic success, was strongly emphasized by the study participants. Students intimate that their institutions were highly politicised, with the SRC further mobilising activities outside the formal governance structures, as Portia (AO2) confirmed, "You know, last year the \#FeesMustFallcampaign ... in a few months we can repeat that". Another example relating to the political infestation within the institutions was lecturers' willingness to listen to SRC members that emanated from political parties to which they were affiliated. Aphiwe (CP2) highlights this,

"From last year we were fighting a lot of battles within the SRC. Fighting about political 
affiliation, so you find that because last year the institution was DASO ... We have our own dynamics within SRC especially last year where in our dealings with the lecturers, depended on which political organisation you came from. If this was different to the lecturer, then you would suffer for it."

He further explained,

"Last year for example, one of the managers of the university was caught by an audio recording when he was saying he was going to kill certain organisations and how. This went viral and he had to leave the university. Even if you want to pass, you must be a politician, everything here you must be a politician if you want to proceed with your life and get your degree you must just be a politician."

Aphiwe's testimony demonstrates the stronghold of politics within the SRC. From this account, it appears that politics had a strong influence on: how students contested, their entry and the way they discharged their duties. The political influence on the SRC was further acknowledged by Andile (AO1). He explained,

"The political interests of SRC members can destabilise the work of the SRC as each party will attempt to serve their own political interests. The work of students is going up and down and will suffer as there will be nothing else that is carried forward."

Andile's comments confirmed that participants' taking on the mantle of political service, compromised not only their own personal academic progress but often impacted other students' academic value.

\section{Time catalyst}

Time seemed to be the catalyst to whether participation in governance had academic value for the participants. All participants described the extensive time commitment necessary for their work in governance, while in many instances struggling with academic work as a result. Typically, a day in the life of the SRC, particularly those in more demanding roles (being involved in all institutional governance committees) was seen to be stressful and exhausting. Mlondi (SG2) indicated that his office was the busiest in the SRC, as a participant in most meetings and further responsible for taking minutes and central to communication by and with the SRC. He had this to say,

"I am the Chief Administrator for the SRC, responsible for writing all documents, minutes, SRC statements to the Student Body and media. I am also responsible for all communication to the various student societies. This means I must participate in all meetings. You end up coming here at six o'clock in the morning and leaving around eleven o'clock at night." 
Lesedi (P1) provided a similar opinion about her experience, saying,

"I sit in a lot of committees which include three meetings of each in the Exco of Council, Institutional Forum, Senate, Student Development, Finance committees. The disadvantage is that it takes a lot of time and is emotionally draining as you spend a lot of time hearing people' problems and sometimes you are devastated when you can't help after spending so much time listening to these problems."

From the accounts by Mlondi and Lesedi, the SRC activities appeared to take up a great deal of time, with their involvement in multiple committees, while further setting aside time for student consultations. This view was echoed by other students for instance, Portia (AO1) who states, "there is too much personal sacrifice, very little time for studies. It is really hard to balance the business of the SRC with what I came here for."

Similarly, Senzile (T2) states,

"The main disadvantage is your time because if you can't manage your time, you are basically disadvantaged. You are expected to attend meetings and at the same time keep up with your courses, without any support."

The strain in prioritising the time between governance and academic activities was further confirmed by Teboho's (SG1) statement,

"Shoo, there are a lot of meetings, but the major meetings that I can talk about are the SRC meetings with management. For us to prepare for the meeting, it takes maybe 3 months, because we get minutes from previous meetings. We have to go through everything so that we are on par with everything that happens in the meeting. We also must plan for what we want to raise at these meetings, although if it is not linked to the agenda, they don't even listen to us."

These excepts suggest a strong realisation by the participants that their roles in governance compromised their study commitments. Worse still, they appeared not to have much influence at these meetings, having spent a lot of time preparing and disregarded when commenting on issues unrelated to the agenda. The resultant high levels of fatigue, would leave very little time for their studies and therefore impact negatively on the prospects for academic success.

\section{Study level}

From the SRC constitutions, all participants are required to have at least passed their studies in the year preceding their entry into the SRC. This implies that all students who participate in 
governance would be obliged to at least have completed their first year of study, thus opening participation to a broader base of students including both undergraduate and postgraduate levels. Evidence drawn from the interaction with the participants showed that the level of study by participants was an important determining factor in the way they experienced their roles in governance. For undergraduates, their daily commitment required that they attend prescheduled classes, at the same time expected to participate in governance meetings both of which would occur during the day. The study programme for postgraduate students was largely researchbased with minimal class attendance necessary. The level of the study would determine participants' agility to perform their roles in governance.

Participants expressed their experience in governance within the context of their study commitment. The main contestation about participating in governance for undergraduate students revolved around their limited exposure not only to governance but that they were still adapting to the broader university experiences. Of concern to them was the volume of coursework, their class and tutorial attendance, which generally took place during the day and thus likely to clash with the meetings that they were expected to attend. Senzile (T2) shares her experience,

\begin{abstract}
"At undergrad, you have to adjust to campus life with many things to juggle including lectures, your social life and now SRC responsibilities. I miss out a lot in parties. You are expected to attend meetings and at the same time attend your courses. I have given up a lot of school time to participate ... I must ask my friends to help me with some of the notes which sometimes are even difficult to understand if I was not in class. In a way I must teach myself which is hard especially after a long day in these meetings."
\end{abstract}

Similarly, Teboho (SG1) expressed his views,

"If I was doing my honours, it would be much easier for me to cope with my studies and my SRC duties, because I don't attend most of the time ... You know you are used to engaging with professors and everything, but in undergraduate, we are in one class, and we are 200 students, so there's not much time to interact."

The struggle with balancing their time at undergraduate as shared by Senzile and Teboho was largely affected by the clash between class attendance and governance meetings. Senzile further alludes to the exclusion from the social aspects of university life, similarly referred in Tinto's (1987) theory of integration. For Teboho, the lack of experience in interacting closely with lecturers given the size of his class, increased the difficulty in networking and interacting with the academic staff in governance meetings. This suggest a likelihood that during meetings he would be withdrawn and not engage with confidence on the discussions especially those on 
academic issues that affected students that he ought to influence.

While admitting to the general challenges faced by undergraduates, Yoliswa (SG3) explains that she is able to cope better having been in the SRC previously, she was better prepared. She explains,

"Last year, being in the SRC compromised my studies. Because of the experience I gained, this year is better and I am able to cope and understand my academics. I can also negotiate my time better as I am in third year and don't have too much pressure now - my modules are manageable and am meeting my deadlines."

The excerpt shows that with maturity and previous exposure in governance, Yoliswa coped with her role. She also points to the reduced volume of work being in her final year of undergraduate study. A similar view was expressed by Thenjiwe (DP1), who was also an undergraduate student, stating,

"I bunk a lot of my classes because of the responsibilities in the SRC. It is difficult to catch up but I try to prioritise this. My reduced attendance in class means that most of what I learn is selftaught. Last semester as a strategy I attended part-time classes so that I could keep up and not compromise my studies as these happened after the meetings in general, say after $5 \mathrm{pm}$. So from 5 $-8 \mathrm{pm}$, I attend part-time lectures as I must graduate this year."

While admitting to the strain in balancing her governance role with her academic commitment, Thenjiwe made an alternate arrangement to attend part-time classes. This however, reduced opportunity for socialisation with other students, an important aspect of her student development.

The experience differed for postgraduates. Lesedi (P1) explains that at postgraduate level, in her case as a Masters student, "you manage your own time". Andile (AO1), also in postgraduate studies, elaborates,

"There is no doubt in my mind that those in post-graduate studies would be far more efficient in helping students out and would have the ability to balance their time better. I think postgraduate is better because you have gone through the challenges from undergraduate. In undergraduate you are still worried about getting a degree whereas in postgraduate at least you have one and you are going for another one. At undergraduate they have a lot of modules to do, so it will be difficult to cope."

Responding to the academic obligation by the SRC, Fana (DSG1) advised,

"Yes, we are an institution of higher learning and the purpose is for us to pursue a qualification and therefore SRC members must have qualifications or at least some academic level. If we 
were not, this is backward thinking. Others say SRC, as cliché, don't take their academics seriously. I can say this is not the case with our team, we have been performing well, with most of us doing post graduate at least in the Executive team. There are four of us with a degree and the others who are not doing postgraduate at least are in their third year."

Fana demonstrates the exemplary leadership anticipated in the SRC. As promoters of academic excellence, stipulated in their constitutions, it would be reasonable to expect that when pursuing this quest for students, they ought to demonstrate their own academic progress.

\section{DISCUSSION}

To persist with their studies, the student who is not in the SRC needs two forms of integration as articulated by Tinto in the integration theory - academic and social. However, the student in the SRC requires to add a third form of integration to the social and academic aspects, what we have termed governance integration. As we argued in the theoretical framework section, in seeking to achieve the latter form of integration, while achieving the former two forms would be useful, but it is not enough. Governance integration also entails getting to grips with other capabilities such as deep understanding of university funding and having to engage with university politics. Evidence from this study suggests that some SRC members did not adequately achieve governance integration despite being involved in University Council and other governance meetings. In Astin's theory of involvement, we learn that such involvement (in this case in seeking to achieve the three forms of integration) should necessarily entail both quality and quantity. The SRC students who simply attended all governance meetings as an expected roll call but did not adequately understand the issues at stake, achieved quantitative but not qualitative involvement. Because governance is time-consuming, these same students also lose out on the quality and quantity of their academic involvement. Therefore, such students' participation in university governance does not add value to their academic experience. However, there is another crop of SRC student who for example work very hard to do well academically because in one of their governance roles they must preside over other students' exclusion on grounds of poor or non-performance, therefore they cannot themselves afford to under-perform.

Evidence suggests that SRC participation in university governance entails multi-tasking on the part of the student because the academic programme does not wait for anybody. This study reveals that the more seasoned the SRC student is in terms of having deeply integrated with the institution both academically and socially, the more they can multi-task. This explains why students in their $3^{\text {rd }}$ year of study or postgraduate, reported more success in balancing their academic and governance roles. A major factor in this matter was a student's time flexibility 
and management. The majority of the students interviewed in this study were undergraduate, which implied that by their own admission, they would struggle to accommodate their academic commitments, never mind opportunity to socialise with other students while fulfilling their roles in governance. The situation was compounded for those students who held more governance responsibilities while in their undergraduate studies, as was the case with the SecretaryGenerals and the Deputy-President interviewed. A more seasoned student is more likely to see participation in university governance adding value to their academic experience than a less seasoned student.

Some students worked their way into the SRC for personal and group interest purposes such as leveraging funds for their studies and representing their political organisations. Others entered the SRC space with a passion to serve. It seems that participation by the former group of students did not add much value to their academic experience because the whole project was neither intended nor envisaged to serve that purpose anyway. However, participation by the latter group did seem to add value. These were students who committed to working hard to succeed academically because that was the way forward to enable them to serve in the SRC and lead by example.

Reflecting on Tinto's assertion about the influence of personal backgrounds on the social and academic integration, our findings have demonstrated that the socio-economic circumstances of some of the participants propelled them to compete for positions in the SRC. However, further evidence from the study shows that once students were in office, the extensive pressure on their duties had a resultant effect of unintended disintegration between their governance and their academic experiences. We found through discussion with the participants that the exhaustive obligation to attend meetings, influenced the shift of their goals and intentions. This was further aggravated by the stipulation in the SRC constitution that failure to attend more than three consecutive meetings could result in expulsion.

The political obligation as stimulated by the support they obtained on elections for positions in the SRC, shifted their goal and commitments. Yet in the constitutions the political objective is not even stated. However, students allude to their plan to express themselves outside of the formal structures, notably their participation in strikes as expressed in the \#FeesMustFall Reloaded (Mosiuao 2016). Perhaps the inclusion of a stipulation in the SRC constitutions on informal governance (Luescher 2008) may serve to contain and manage student strikes that fell outside of the mandatory governance structures. Notably the SRC must account for strikes at formal university engagements, albeit not always responsible nor in the forefront of these actions. Such strike action, especially when disruptive to the university academic calendar and in certain instances destroying the facilities provided for student learning, further derails the 
SRC member from their own academic progress.

The findings of the study further attest to Astin's (1984) theory of involvement. Firstly, the observed emotional and physical strain expressed by the participants appear to have swung the pendulum towards the negative effect of governance participation on their academic objectives. The inability by some of the participants to prioritise between assumed responsibilities (governance) and their own commitments (academic development), further adds to this dilemma. To translate the theory practically, would necessitate that academic policies in the SRC constitutions would need to be enhanced. The academic substance ought to be better clarified and applied during their term in office as opposed to being confined to entry obligations. The conundrum of students' experience and development would be better aligned to the academic objective set out. This necessitates that the blueprint (SRC constitution) to student participation in governance should be more effective in directing how the academic value is achieved.

\section{CONCLUSION}

Participation in university governance does not always add value to students' academic experience. It takes a tripartite form of integration with the institution for such participation to bear academic fruit. Failure to achieve this three-pronged integration can have devastating effects, not only on one's academic life but also on their usefulness in university governance.

This study has shown that the academic value of student participation in university governance is expressed and influenced by a variety of issues. Amongst the key drivers to students' academic gain, include the effect of political deployment, level of study and their own ability to balance their time. Based on these permutations, participation in governance does add academic value to some of the participants. Further, to enhance the value of the SRC academic objectives, would imply considered revision of the SRC constitutions as the blueprint to how they participate in governance in relation to their academic pursuits. With the achievement of free education, to address the economic challenges faced by students means that an overhaul of how the SRC achieves academic development for students in general and for themselves, will be a subject for deeper interrogation.

\section{REFERENCES}

Altbach, P. G. 2006. Student politics: Activism and culture. In International handbook of higher education, ed. J. F. J. Forest and P. G. Altbach. Dordrecht. Springer.

Altbach, P. G. and R. Cohen. 1990. American student activism: The post-sixties transformation. The Journal of Higher Education 61(1): 32-49.

Astin, A. W. 1984. Student involvement: A developmental theory for higher education. Journal of 
College Student Personnel 25(4): 297-308.

Astin, A. W. 1999. Student involvement: A developmental theory for higher education. Journal of College Student Development 40: 518-529.

Badat, S. 1999. Black student politics. Pretoria: HSRC Publishers.

Bless, C., C. Higson-Smith and S. L. Sithole. 2013. Fundamentals of social research methods: An African perspective. $5^{\text {th }}$ Edition. Cape Town: Juta and company Ltd.

Bonakele, T., T. Mxenge, S. Thabakgale and O. J. J. Tabane. 2003. Student Representative Councils: A guide to developing a constitution. Rondebosch: centre for Higher Education Transformation.

Bowen, G. A. 2009. Document analysis as a qualitative research method. Qualitative Research Journal 9(2): 27-40.

Boyce, C. and P. Neale. 2006. Conducting in-depth interviews: A guide for designing and conducting in-depth interviews for evaluation input. Watertown, MA: Pathfinder International.

Bryman, A. 2008. Ethics in qualitative psychological research. The Sage handbook of qualitative research in psychology 24(2): 263-279.

Cele, M. 2008. The contradictory and complimentary relationship between student constructive engagement and protest strategies in South African Higher Education. Department of Science and Technology 6(2): 77-106.

Cele, G. and C. Koen. 2003. Student politics in South Africa. An overview of key developments. Paris: Foundation Maison des Sciences de l'Homme.

Cohen, L., L. Manion and K. Morrison. 2007. Validity and reliability. Research Methods in Education, 133-164. London: Routledge.

Davies, J. 1996. The state and the South African university system under apartheid. Comparative Education 32(3): 319-332.

Klemenčič, M. 2014. Student power in a global perspective and contemporary trends in student organising. Studies in Higher Education 39(3): 396-411.

Koen, C., M. Cele and A. Libhaber. 2006. Student activism and student exclusions in South Africa. International Journal of Educational Development 26(4): 404-414. doi: http://dx.doi.org/ 10.1016/j.ijedudev.2005.09.009

Lewis, J. and J. Ritchie. 2003. Generalising from qualitative research. Qualitative Research Practice: A Guide for Social Science Students and Researchers 2: 347-362.

Luescher, T. M. 2008. Student governance in transition: University democratisation and managerialism: A governance approach to the study of student politics and the case of the University of Cape Town. Ph.D. dissertation, University of Cape Town.

Luescher, T. M. and M. Klemenčič. 2017. Student power in twenty-first century Africa: The character and role of student organizing. Student Politics and Protests: International Perspectives: 113127.

Luescher, T., L. Loader and T. Mugume. 2017. \#FeesMustFall: An Internet-age student movement in South Africa and the case of the University of the Free State. Politikon 44(2): 231-245.

Mapesela, M. and H. R. Hay. 2005. Through the magnifying glass: A descriptive theoretical analysis of the possible impact of the South Africa higher education policies on academic staff and their job satisfaction. Higher Education 50(1): 111-128.

Mazwai, N. 2008. SaiSai-Little girl. Johannesburg, South Africa: Gcwanini Marketing and Entertainment.

Merriam, S. B. 2009. Qualitative research: A guide to design and interpretation. San Francisco: JosseyBass.

Mosiuao, T. 2016. September 21 Fees Must Fall Reloaded: What does it all mean? OkayAfrica. http://www.okayafrica.com/fees-must-fall-reloaded-south-africa-student-protests

Nyundu, T., N. Naidoo and T. Chagonda. 2015. Getting involved on campus: Student identities, student 
politics, and perceptions of the Student Representative Council (SRC). Journal of Sociology Anthropology 6(1):149-161.

Reddy, T. 2004. Higher education and social transformation. South Africa case study. Pretoria: Council on Higher Education.

Robus, D. and C. Maclead. 2006. White excellence and black failure: The reproduction of racialised higher education in everyday talk. South African Journal of Psychology 36(3): 463-480.

Silverman, D. 2011. Interpreting qualitative data: A guide to the principles of qualitative research. $4^{\text {th }}$ Edition. London: SAGE.

Soudien, C. 2010. Grasping the nettle? South African higher education and its transformative imperatives. South African Journal of Higher Education 24(5): 881-896.

Thathiah, D. 2016. Library torched in Nazi-style book burning after student raped by police in South Africa university fee protests. eNCA Live September 7.

Tinto, V. 1987. Leaving college: Rethinking the causes and cures of student attrition. Chicago: University of Chicago Press.

Tinto, V. 1993. Leaving college: Rethinking the causes and cures of student attrition. $2^{\text {nd }}$ Edition. Chicago: University of Chicago Press.

Yin, R. K. 2003. Case study research: Design and methods. $3^{\text {rd }}$ Edition. Thousand Oaks, CA: Sage. 